\title{
Analysis and Research on Improving Teachers' Teaching Ability by Information Technology and Distance Education Training Program
}

\author{
Chinmayshtha Sharmi \\ Academic Associate, Yashwantrao Chavan Maharashtra Open University, Nashik, MH, India
}

\begin{abstract}
As Covid-19 pandemic era taught us the importance of use of technology in each area of our daily living. Education is also not an exception. During this pandemic, the support of information communication technology has handled the process of educating our young generation efficiently. The Information Communication Technology is really a blessing in Today's world. It has been proven that no boundary can stop communication between people. The purpose of the present study also examined the effect of the refresher program on the topic Application of ICT and education" on in service special educators. Therefore the 18 hours training program was implemented as a refresher course approved by the Rehabilitation Council of India, New Delhi. The Study sample included 30 special educators from the various states. This program was organized through online mode. The effectiveness was calculated through studying the difference between pre and post test before and after the course using t-test. The result of the study shown significant difference between the scores obtained in pre test and post tests. It means the refresher course enhanced the skills and knowledge about ICT in Special teachers.
\end{abstract}

Keywords: Special educators, refresher program, Information Communication Technology

\section{Introduction}

ICT stands for "Information and communication technology". It refers to technologies that provide access to information through telecommunication. This includes the internet, wireless networks, cell phones and other communication mediums. It means we have more opportunities to use ICT in teacher training programs now days and improve quality of teacher for teach effectively. According to UNESCO "ICT is a scientific, technological and engineering discipline and management technique used in handling information, its application and association with social, economic and cultural matters. As Teacher is the most important pillar of the education system, ICT is also one of the important pillars of the teaching learning process. ICTs are making vibrant changes in society. They are influencing all aspects of life. The influences are felt more and more at schools. Because ICTs provide both students and teachers with more opportunities in adapting learning and teaching to individual needs, society is, forcing schools aptly respond to this technical innovation.

\section{ICT and person with Disability:}

Information and communication technologies (ICT), when accessible and available, can serve as significant enablers that allow persons with disabilities to realize full and effective opportunities to participate, on the basis of equality, in all aspects of society and development. ICTs can help persons with disabilities have a greater access to knowledge and independent living. Accessibility is one of eight fundamental principles in the Convention on Rights of Person with Disability (CRPD 2006). It is defined as a precondition for persons with disabilities to enjoy all rights and fundamental freedoms, including the rights to life and liberty, education, employment, cultural materials, sports and entertainment, political participation and movement.
Earlier studies have shown that the suitable use of ICT can enhance quality of teaching learning process as well as interpersonal communication and connect it to the actual life situations (Lowther, et al.2008; Weert and Tatnall 2005). Kent and Facer (2004) indicated that school is an important environment in which students participate in a wide range of computer activities, while the home serves as a complementary site for regular engagement in a narrower set of computer activities and increasingly, ICT is being applied successfully in instruction, learning, and assessment. ICT is considered a powerful tool for educational change and reform. As Weert and Tatnall (2005) have pointed out, learning is an ongoing lifelong activity where learners change their expectations by seeking knowledge, which departs from traditional approaches. As time goes by, they will have to expect and be willing to seek out new sources of knowledge. Skills in using ICT will be an indispensable prerequisite for the learners. The mediator between the ICT and the teaching learning process is the teacher. Teacher has a very important role to play in student's life. Teachers make the world a better place to live in. They set a tone of the school, mentor \& teach children \& nurture them well. That's why the role of the teacher as a moral guide is critical in one's life. Today we should know that only teacher can change the economic, moral \& social life of an individual and so they have to be up-to-date in gaining knowledge about the advancements of the field as well as new technology or ICT for effective teaching and mentoring their students. The special Educator must be aware and gain knowledge of various advance technologies and assistive devices which are useful to make life more convenient and accessible to the students with impairment. Hence this study is one of the efforts to make these teachers aware about the information regarding ICT and advancement in the field of Special education in view of technology.

Objective of the study: To compare the achievement of special educators in the time period of three days refresher 
program on application of ICT and education using the scores of pre and post test.

Hypothesis: There will be no significant difference in mean gain of pre test and post test for ICT

\section{Methodology}

A quasi experimental single group pre test-post test design was adopted for the present study. Group of 30 teachers were considered as a sample for the study. These teachers were from the special as well as inclusive school's background. They are working teachers and enrolled in the refresher program for the carrier advancement. The knowledge about ICT and Technology were assessed through the pre test with 25 multiple choice questions which were based on the topics, such as concept of ICT, assistive devices, meaning of abbreviations, levels of technology, Microsoft word, Microsoft power-point, online education, online resources etc. after pre test the training was organized within a time frame of 18 hours. In these 18 hours 12 hours weitage given for the theory as well as demonstration and six hours were for hands on experience. Teachers were asked to create one word file one PPT and one Google classroom showing all the options given in the menu of system such as make the text bold, change the color of the text, insert table, etc. same way for power point adding a new slide, inserting hyperlink, sound or video in PPT, making slide show, assigning specific animation effect to the slides etc. In Google classroom the training was focused on adding students, assigning roles, publishing assignment for particular students, checking assignment, marking etc. after completing whole 18 hours training the post test was given and teachers answered the same questions in post test.

\section{Data analysis}

The non parametric t-test was used to analyze data. Following table is showing the pre test post test scores.

Comparison of overall means of post test and pre test scores

\begin{tabular}{|c|c|c|c|c|c|c|c|c|}
\hline \multirow{3}{*}{$\frac{\text { Total }}{\text { Overall achievement }}$} & \multicolumn{2}{|c|}{ Mean } & \multirow{2}{*}{ Mean gain } & \multicolumn{2}{|c|}{ t-value } & \multirow{2}{*}{$\mathrm{df}$} & \multirow{2}{*}{$\begin{array}{l}\text { Significance } \\
\text { level at } 0.05\end{array}$} & \multirow{2}{*}{$\mathrm{H}_{0}$} \\
\hline & Post test & Pre test & & Cal. value & Critical & & & \\
\hline & 19.20 & 11.23 & 7.97 & 2.04 & 1.69 & 29 & Significant & Rejected \\
\hline
\end{tabular}

The above Table shows that the obtained t-value for overall achievement in gaining knowledge about ICT is greater (2.04) than critical t-value (1.69). Hence the null hypothesis framed is rejected and alternate is retained. It means that the overall mean score for post-test (19.20) is significantly greater than its corresponding overall mean score of pre-test (11.23). Therefore it may be concluded that the refresher training program is effective in developing ICT skills in special educators.

\section{Discussion}

The researcher observed struggle to accept the use of ICT among the entire participant. All the participants were giving justifications in a negative manner that how the ICT has messed up the learning of the students and teacher's role as well. But after three days same participants were happy to share various assignments on ICT and changed their attitude to positive for ICT. They also developed confidence for using basic features of MS word, MS power-point and Google classroom. They enjoyed working on the Google classroom and appreciated the benefits. Hence as per the reviewed literature present study also supports the fact that refreshing and enhancing knowledge through refresher programs regarding ICT use in classroom teaching is beneficial for special Educators.

\section{Conclusion}

The present study concludes that the three days refresher program on ICT impacted positively and enhanced the knowledge as well as the confidence and developed positive attitude towards using ICT in classroom teaching in Special educators.

\section{References}

[1] Khoroshilov, A. (2010). UNESCO teacher development policies and programmes including ict. ICT in Teacher Education, 18.

[2] Onyema, O. G., \& Daniil, P. (2017). Educating the 21st century learners: are educators using appropriate learning models for honing skills in the mobile age? Journal of Entrepreneurship Education, 20 (2), 1-15.

[3] Perlin, M. L. (2011). International human rights and mental disability law: When the silenced are heard. Oxford University Press.

[4] Ratheeswari, K. (2018). Information communication technology in education. Journal of Applied and Advanced research, 3 (1), 45-47.

[5] Kent, N., \& Facer, K. (2004). Different worlds? A comparison of young people's home and school ICT use. Journal of computer assisted learning, 20 (6), 440-455.

[6] Lowther, D. L., Inan, F. A., Daniel Strahl, J., \& Ross, S. M. (2008). Does technology integration "work" when key barriers are removed? Educational Media International, 45 (3), 195-213.

[7] van Weert, T. J., \& Tatnall, A. (Eds.). (2005). Information and communication technologies and reallife learning: new education for the knowledge society (Vol.182). Springer Science \& Business Media. 